\title{
Specific Caspase Pathways Are Activated in the Two Stages of Cerebral Infarction
}

\author{
Alexandra Benchoua, ${ }^{1}$ Christelle Guégan, ${ }^{3}$ Cécile Couriaud, ${ }^{1}$ Hassan Hosseini, ${ }^{1}$ Nathalie Sampaïo, ${ }^{1}$ \\ Didier Morin, ${ }^{2}$ and Brigitte Onténiente ${ }^{1}$ \\ 1/nstitut National de la Santé et de la Recherche Médicale, Unité 421/IM3, and 2Laboratoire de Pharmacologie, \\ Faculté de Médecine, F-94010 Créteil Cedex, France, and ${ }^{3}$ Department of Neurology, Columbia University, New York, \\ New York 10032
}

Necrosis and apoptosis have been initially identified as two exclusive pathways for cell death. In acute brain lesions, such as focal ischemia, this binary scheme is challenged by demonstrations of mixed morphological and biochemical characteristics of both apoptosis and necrosis in single cells. The resulting difficulty in defining the nature of cell death that is triggered by severe insults has dramatically impeded the development of therapeutic strategies. We show that in the early stages of cerebral infarction, neurons of the so-called "necrotic" core display a number of morphological, physiological, and biochemical features of early apoptosis, which include cytoplasmic and nuclear condensations and specific caspase activation cascades. Early activation cascades involve the death receptor pathway linked to caspase- 8 and the caspase- 1 pathway. They are not associated with alterations of mitochondrial respiration

After arterial occlusion, the central lesion, or core, is conventionally considered necrotic (Garcia et al., 1995; Lipton, 1999), whereas the bordering area, or penumbra, recruits apoptotic mechanisms (Linnik et al., 1993; Li et al., 1995; CharriautMarlangue et al., 1996). After permanent occlusion of the middle cerebral artery (MCAO), the most severe paradigm for focal ischemia (Mao et al., 1999), massive pan-cellular death in the core is achieved within $3 \mathrm{hr}$, and total infarction is observed at 24 hr (Guégan et al., 1998). Yet, in such a pro-necrotic setting, several characteristics of apoptosis have been observed, including cell shrinkage, reduction of infarct volume by cycloheximide or overexpression of Bcl-2, reduced vulnerability of p53 knock-out transgenic mice, and activation of caspases in the core (Choi, 1996; Velier et al., 1999; Guégan and Sola, 2000). However, the full panel of morphological changes indicating apoptosis is never observed at the end stages of infarction; instead, neurons display mixed characteristics of necrosis and apoptosis. This has led to the controversial theory (Roy and Sapolsky, 1999; Fujikawa, 2000) that cell death proceeds via a number of hybrid pathways among a continuum between both extremes (Martin et al., 1998).

An alternative explanation is offered by the attractive concept

\footnotetext{
Received April 17, 2001; revised July 5, 2001; accepted July 9, 2001.

We thank Dr. Anu Srinivasan (Idun Pharmaceuticals, La Jolla, CA) and Dr. Frank Barone (SmithKline Beecham, King of Prussia, PA) for kindly providing anti-caspase antibodies. We thank Dr. M. Peschanski and Professor W. Neckameyer for critical review of this manuscript.

Correspondence should be addressed to Dr. Brigitte Onténiente, Institut National de la Santé et de la Recherche Médicale, Unité 421, 8, rue du Général Sarrail, F-94010 Créteil Cedex, France. E-mail: ontenien@im3.inserm.fr.

Copyright (ㄷ) 2001 Society for Neuroscience $0270-6474 / 01 / 217127-08 \$ 15.00 / 0$
}

or activation of caspase-9. In contrast, pathways that are activated during the secondary expansion of the lesion in the penumbral area include caspase-9. In agreement with its downstream position in both mitochondria-dependent and -independent pathways, activation of caspase- 3 displays a biphasic time course. We suggest that apoptosis is the first commitment to death after acute cerebral ischemia and that the final morphological features observed results from abortion of the process because of severe energy depletion in the core. In contrast, energy-dependent caspase activation cascades are observed in the penumbra in which apoptosis can fully develop because of residual blood supply.

Key words: apoptosis; caspase; cortex; mitochondria; necrosis; stroke

that, under anoxic-ischemic conditions, apoptosis may be masked by necrosis (Choi, 1996). In vitro studies have provided several examples of shifts toward apoptosis from necrosis, resulting from abrupt environmental perturbations (Gwag et al., 1995) or from modifications of intrinsic determinants of cell death, such as ATP (Leist et al., 1997; Nicotera et al., 1998) or nitric oxide (Melino et al., 2000).

Caspases are among the gene products that are implicated in the control of apoptosis (Li and Yuan, 1999; Hengartner, 2000). Caspases cleave a variety of protein substrates (Nicholson and Thornberry, 1997), leading to cell disintegration in a strikingly efficient manner (Cohen, 1997). Given the number and diversity of caspase targets, most, if not all, of the morphological features described for apoptosis are caspase-dependent. Caspases participate in cascades that include initiator and effector caspases (Friedlander et al., 1997; Fink et al., 1998), which are both activated by ischemia (Schielke et al., 1998; Plesnila and Moskowitz, 2000). Administration of caspase inhibitors before, or soon after, ischemia consistently reduces the volume of infarcted tissue and the extent of neurological failure, confirming their involvement in the neurodegenerative process (Hara et al., 1997; Endres et al., 1998; Himi, 1998). However, although caspase activation is generally described in spatiotemporal relationships with delayed cell death, i.e., in the penumbra for focal infarcts, immunohistochemical analysis in MCAO has shown neurons containing caspase-3 in the infarct core (Velier et al., 1999; Guégan and Sola, 2000). This suggests that either caspases can be activated in nonapoptotic types of cell death or apoptosis is a cell death pathway in necrotic ischemic cores. 
We have therefore reexamined the notion that apoptosis could be the first commitment to death after acute cerebral ischemia and that the final necrotic morphological appearance results from a secondary shift attributable to the severity of the insult.

\section{MATERIALS AND METHODS}

Surgical procedure. Studies were performed on C57BL/6 male mice aged 8 weeks (25-30 gm; Janvier, Le Genest St-Isle, France). Permanent focal cerebral ischemia was performed by electrocoagulation and section of the left MCA according to Shigeno et al. (1985). Sham-operated animals were subjected to the same procedure, without MCA electrocoagulation and section. Animals were killed $30 \mathrm{~min}$ or $1,3,6,12$, or $24 \mathrm{hr}$ after MCAO. Naive control mice were also examined.

Caspase activity assay. Protein fractions were isolated from the MCA territory that was dissected out of the hemicortex of ischemized, shamoperated, and naive animals. Tissues were suspended in a lysis buffer [Tris base $50 \mathrm{~mm}, \mathrm{pH} 7.4, \mathrm{NaCl} 150 \mathrm{~mm}$, Triton X-100 0.5\%, EDTA 1 $\mathrm{mM}$, protease inhibitor cocktail $0.5 \%$ (Sigma, St. Louis, MO)] and were homogenized using a manual potter. Homogenates were centrifuged at $13,000 \times g$ for $30 \mathrm{~min}$, and supernatants were aliquoted and stored at $-80^{\circ} \mathrm{C}$. Caspase catalytic activities were measured on synthetic substrates linked to 7-amino-4-trifluoromethyl-coumaryl (AFC) (Biomol, Plymouth Meeting, PA), ac-YVAD-AFC, ac-VDVAD-AFC, ac-DEVDAFC, ac-IETD-AFC, and ac-LEHD-AFC, for caspase-1, -2, -3, -8, and -9 , respectively. Proteins $(30 \mu \mathrm{g})$ were diluted in caspase assay buffer (in mM: HEPES 50, pH 7.4, NaCl 100, EDTA 1, DTT 10) to a final volume of $90 \mu \mathrm{l}$. The enzymatic reaction was started by the addition of $10 \mu \mathrm{l}$ of a $2 \mathrm{~mm}$ solution of the appropriate substrate and incubated for $2 \mathrm{hr}$ at $37^{\circ} \mathrm{C}$. Quantification of substrate cleavage leading to the release of free AFC was performed at an excitation of $400 \mathrm{~nm}$ and an emission of 505 nm. Measurements were performed on a PerkinElmer LS 50B spectrofluorimeter (PerkinElmer Life Sciences, Norwalk, CT). Fluorescent arbitrary units were converted into micromoles of AFC released per hour and milligrams of protein using a standard curve of free AFC (Biomol).

Western blot analysis. Twenty-five micrograms of protein were boiled at $100^{\circ} \mathrm{C}$ in a buffer containing sucrose $(20 \%)$, SDS (2.4\%), $\beta$-mercaptoethanol $(5 \%)$, and bromophenol blue $(5 \%)$. They were then resolved on a $15 \%$ SDS-PAGE gel and electrophoretically transferred onto polyvinylidene difluoride membranes. Membranes were blocked with 5\% nonfat dry milk in PBS containing $0.1 \%$ Tween 20 and were probed with rabbit polyclonal anti-active caspase-3 (CM1; 1/1000; Idun Pharmaceuticals, La Jolla, CA), anti-active (p18) caspase- 8 and anti-pro-caspase- 8 (SK440 and SK441, respectively; 1/1000; SmithKline Beecham, Harlow, UK), or anti-caspase-1 (M-19; 1/1000; Santa-Cruz Biotechnology, Tebu, France) antibodies in TBS-Tween 20 containing 5\% nonfat dry milk overnight at $4^{\circ} \mathrm{C}$. After incubation with goat anti-rabbit-HRP $(1 / 8000$; Amersham Pharmacia Biotech, Les Ulis, France) $1 \mathrm{hr}$ at room temperature, antigens were revealed by enhanced chemiluminescence reaction (Amersham ECL + ). Blots were routinely stripped in a denaturating buffer (Tris $\mathrm{HCl} 0.5 \mathrm{M}, \mathrm{pH} 6.8$, SDS $10 \%, \beta$-mercaptoethanol $0.8 \%$ ) and reprobed with anti- $\alpha$-tubulin antibodies (1/5000; Sigma) for $1 \mathrm{hr}$ at room temperature as a loading control. Quantitative results were normalized to $\alpha$-tubulin contents, as described by Harrison et al. (2000). To further control SK440 antibody specificity, the working solution was preadsorbed

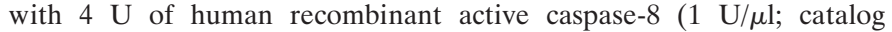
\#CC123; Chemicon, Temecula, CA,) at $4^{\circ} \mathrm{C}$ overnight and was applied on the membranes.

Analysis of caspase-3 mRNA contents. Isolation of total mRNA from ipsilateral hemicortices was performed in TRIzol reagent (Promega, Charbonnieres, France) ( $1 \mathrm{ml}$ of TRIzol/50 mg of tissue), followed by reverse transcription with M-MLV reverse transcriptase (Promega) according to the manufacturer's instructions. For PCR, $1.5 \mu \mathrm{g}$ of cDNA were mixed with $1 \mathrm{~mm} \mathrm{MgCl}, 0.2 \mathrm{~mm}$ dNTP, 1 IU DNA polymerase, and $0.2 \mu \mathrm{M}$ of the following primers: forward 5'-GGG AGC TTG GAA CGG TA and reverse $5^{\prime}$-CAG TAG TCG CCT CTG AAG AAG. PCR was run at $94^{\circ} \mathrm{C}$ for $3 \mathrm{~min}$, followed by 30 cycles at $94^{\circ} \mathrm{C}$ for $45 \mathrm{sec}, 52^{\circ} \mathrm{C}$ for $45 \mathrm{sec}$, and $72^{\circ} \mathrm{C}$ for $45 \mathrm{sec}$, and was ended at $72^{\circ} \mathrm{C}$ for $5 \mathrm{~min}$. For each point, the housekeeping gene GAPDH was used as a control with the following primers: forward 5'-GTG ATG CTG GTG CTG A and reverse 5'-GCT AAG CAG TTG GTG G. The annealing temperature and cycle number were chosen such that both the caspase-3 and the GAPDH PCR products would be in the linear phase of amplification and of similar intensity. The PCR products were of $477 \mathrm{bp}$ for caspase-3 and of $214 \mathrm{bp}$ for GAPDH. Quantitation was performed by reporting caspase-3 mRNA contents to GAPDH mRNA contents, according to Harrison et al. (2000).

Immunohistochemistry. Mice were deeply anesthetized with $4 \%$ chloral hydrate $(500 \mathrm{mg} / \mathrm{kg})$ and perfused with $4 \%$ paraformaldehyde. Brains were removed, post-fixed overnight in the same fixative, and embedded in paraffin. Ten micrometer-thick sections were collected on glass slides, treated with toluene to remove paraffin, and rehydrated. Sections were incubated overnight at $4^{\circ} \mathrm{C}$ in $0.1 \mathrm{M}$ PBS containing $0.3 \%$ Triton $\mathrm{X}-100$ (PBS-T) with primary antibodies (CM1, 1/3000; SK440, 1/5000), glial fibrillary acidic protein (GFAP; monoclonal antibodies clone G-A-5; 1/5000; Boehringer Mannheim, Mannheim, Germany). Sections were washed and incubated in biotinylated anti-rabbit antibodies (1/300 in PBST; Vector Laboratories, Burlingame, CA) for $1 \mathrm{hr}$ at room temperature, then in streptavidin-biotin-peroxidase complex for $1 \mathrm{hr}(1 / 300$, Vector Elite; Vector Laboratories); they were processed using the Tyramide amplification system (NEN, Boston, MA) with Cyanin-3. For double labelings, sections were processed for CM1 staining and washed in glycine buffer (glycine $0.1 \mathrm{M}, \mathrm{pH} 3.34$ ) for 10 min to detach immunoglobulins and avoid false-positive staining with secondary antibodies from the second reaction (Nakane, 1968). Then, they were washed in PBS and processed for SK440 or GFAP staining as described above, with FITC for second fluorophore. Bisbenzimide $(0.5 \mu \mathrm{g} / \mathrm{ml}$; Sigma $)$ was added to the last incubation medium to visualize nuclear morphology. To further evaluate the specificity of the CM1 and SK440 antibodies in our conditions, working dilutions of the primary antibodies (CM1 or SK440) were adsorbed overnight at $4^{\circ} \mathrm{C}$ with $2 \mathrm{U}$ of recombinant active human proteins (caspase-3, catalog \#CC119; or caspase-8, respectively; Chemicon). The antibody mixture was used for immunohistochemistry as described above. Images were collected with a Zeiss Axioplan II microscope equipped with a Coolsnap digital camera (Photometrics; Zeiss, Le Pecq, France) and the AxioVision sofware (Zeiss, Oberkocken, Germany).

Assay of mitochondrial oxygen consumption. Cerebral mitochondria were isolated according to Zini et al. (1996) on pooled $(n=4)$ cortices ipsilateral to the occlusion. Oxygen consumption was measured with a Clarke-type $\mathrm{O}_{2}$ microelectrode in a thermostatically controlled $\left(37^{\circ} \mathrm{C}\right)$ chamber. Mitochondria $(0.25 \mathrm{mg})$ were added to $0.5 \mathrm{ml}$ of respiration

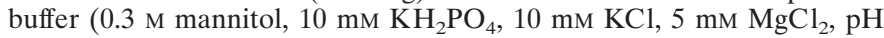
7.2). Mitochondrial respiration was initiated by the addition of $3 \mu l$ of glutamate and $3 \mu \mathrm{l}$ of $1 \mathrm{M}$ malate, and oxidative phosphorylation was initiated by addition of $0.2 \mathrm{~mm}$ ADP. Three independent experiments were performed with three points for each condition, i.e., a total of 27 mice.

Intracerebroventricular administration of caspase inhibitors. Mice received $300 \mathrm{ng}(0.5 \mu \mathrm{l}$ in sterile saline) of Ac-YVAD-CMK (Biomol) Ac-IETD-FMK (Promega), or vehicle $30 \mathrm{~min}$ before MCAO. Injections were performed stereotaxically into the right lateral ventricle over $5 \mathrm{~min}$. Mice were killed $1 \mathrm{hr}$ after MCAO, and caspase assays were performed as described.

Statistical analysis. Data are expressed as mean \pm SEM. One-way ANOVAs were used to compare intergroup differences in protein expression or in caspase activities, followed with post hoc testing (indicated in legends) for differences with a minimal $p$ value of $<0.05$ for significance.

\section{RESULTS}

\section{Caspase- 3 is activated in neurons with apoptotic characteristics in the core of a focal infarct}

The expression and activity of caspase- 3 was analyzed over time. As revealed by cleavage of its substrate ac-DEVD-AFC (Table 1), the proteolytic activity of caspase-3 was strongly increased $1 \mathrm{hr}$ after occlusion. A second wave of activation occurred around 12 $\mathrm{hr}$, in agreement with the secondary expansion of the lesion by apoptosis.

Because DEVD-AFC can act as a substrate for other caspases (Nicholson and Thornberry, 1997; Garcia-Calvo et al., 1998), the involvement of caspase- 3 in the cleavage was confirmed by Western blotting with antibodies specific for the active (p20) form of caspase-3. P20 levels were specifically increased $1 \mathrm{hr}$ after the occlusion (Fig. 1 $A, B$ ). No other band was observed on the blots, confirming the specificity of CM1 antibodies. Analysis of brain extracts from naive animals showed that the presence of a band in 


\begin{tabular}{|c|c|c|c|c|c|c|c|}
\hline Caspase & Sham & $30 \mathrm{~min}$ & $1 \mathrm{hr}$ & $3 \mathrm{hr}$ & $6 \mathrm{hr}$ & $12 \mathrm{hr}$ & $24 \mathrm{hr}$ \\
\hline-3 & $62.5 \pm 0.44$ & $63 \pm 0.4$ & $116 \pm 10.6^{*}$ & $76.6 \pm 3.5$ & $40.06 \pm 3.8$ & $100.6 \pm 6.1^{*}$ & $34.26 \pm 5.5$ \\
\hline-9 & $257 \pm 58$ & $260 \pm 50$ & $348 \pm 34$ & $566 \pm 34 * *$ & $540 \pm 20^{*}$ & $262 \pm 50$ & $536 \pm 78 *$ \\
\hline-2 & $106.8 \pm 18$ & $123.6 \pm 16$ & $114.4 \pm 21$ & $129.9 \pm 16$ & $90.2 \pm 14.7$ & $72.8 \pm 16.6$ & $65 \pm 12.8$ \\
\hline-8 & $157 \pm 15.7$ & $412 \pm 27^{* *}$ & $414 \pm 25^{* *}$ & $134 \pm 4.4$ & $176 \pm 5.3$ & $280.4 \pm 33^{*}$ & $142.5 \pm 10.2$ \\
\hline-1 & $153.09 \pm 2$ & $419.46 \pm 45^{* *}$ & $322.45 \pm 40^{*}$ & $110.54 \pm 12$ & $148.54 \pm 3.2$ & $385.9 \pm 40^{*}$ & $153.99 \pm 0.2$ \\
\hline
\end{tabular}

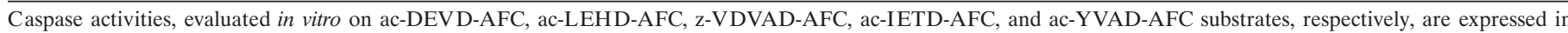

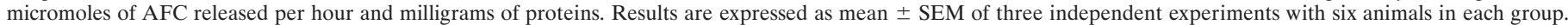
One-factor ANOVA with Scheffe F test: ${ }^{*} p<0.05$, * ${ }^{*} p<0.01$, versus sham.

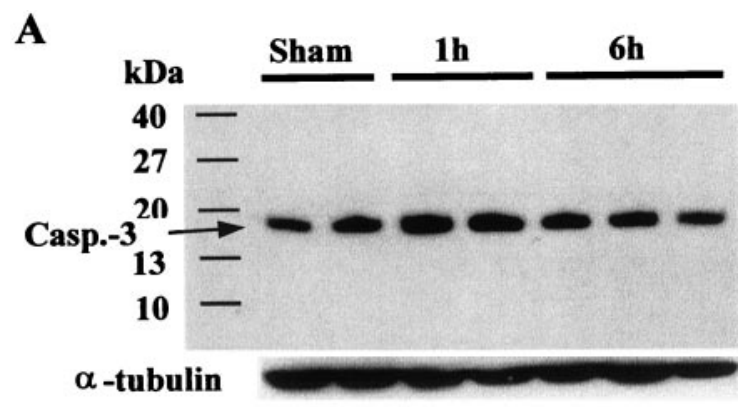

B

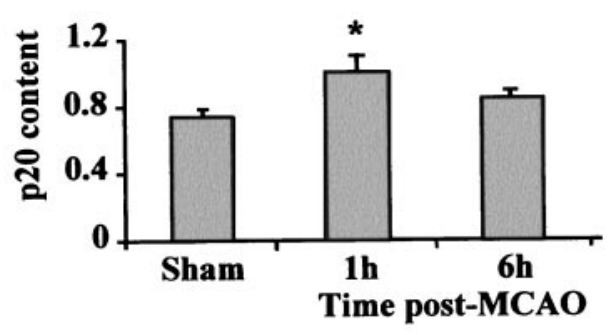

C

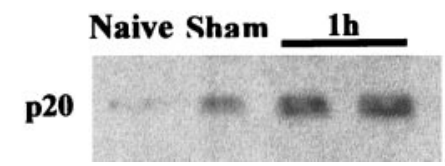

Figure 1. Rapid activation of caspase- 3 in focal MCAO. Protein contents $(A)$ and respective quantitative analysis $(B)$ of active caspase-3 detected by immunoblotting using CM1 antibodies. Error bars represent mean \pm SEM of six animals. Experiments were performed in duplicate. ${ }^{*} p<0.05$, one-factor ANOVA with Scheffe F test.

sham animals was attributable to the anesthesia and presurgical conditions (Fig. 1C).

To determine whether caspase-3-containing cells were located in the core or in the penumbra at $1 \mathrm{hr}$ after MCAO, we stained for expression of p20 on perfusion-fixed tissue sections. The p20 protein was observed in cortical layers III-VI, with a majority of cells in layers IV-V (Fig. 2A). No staining was observed on sections incubated with adsorbed primary antibodies (Fig. 2B). A few stained cells were also observed in the somatosensory cortex contralateral to the lesion. Double labelings with the astroglial marker GFAP showed no colocalization (data not shown), suggesting a main expression in neurons. Neurons containing active p20 protein consistently exhibited nuclear condensation (Fig. $2 E, F)$.

Activation of caspase-3 $1 \mathrm{hr}$ after MCAO was not associated with a decrease in the $32 \mathrm{kDa}$ inactive pro-caspase- 3 protein contents (data not shown), suggesting a sustained transcriptional
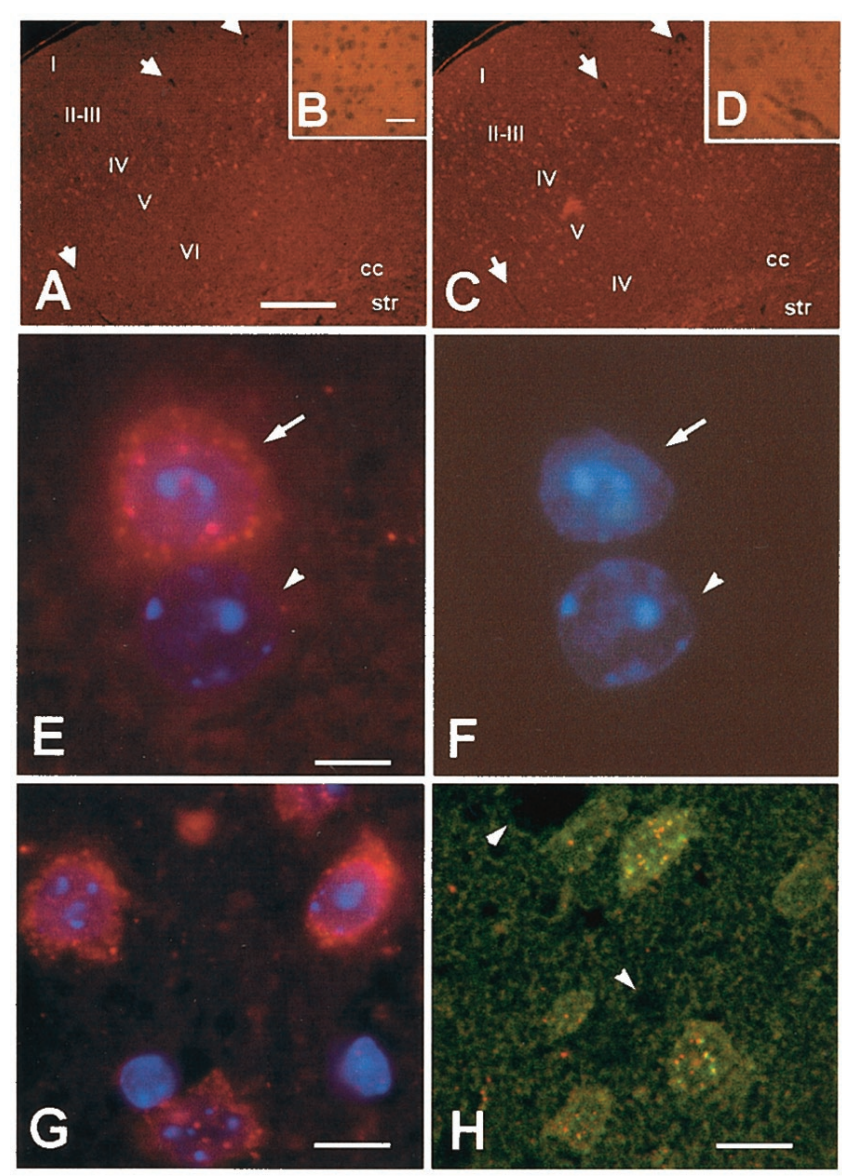

Figure 2. Activated caspase- 3 and caspase- 8 are located in the infarct core $1 \mathrm{hr}$ after MCAO. A, Active caspase-3 (CM1 antibodies) labeling encompasses layers IV-V, in which the first signs of structural alterations are observed. $B$, No labeling is observed on sections treated with preadsorbed antibodies. $C$, On an adjacent section, active caspase-8 (SK440 antibodies) is more widely distributed but is also observed in cells of layers IV-V. $D$, No labeling is observed on sections treated with preadsorbed antibodies. Arrows in $A$ and $C$ indicate similar blood vessels on the adjacent sections. I-VI indicate the cytoarchitectural divisions of the mouse parietal cortex. $E, F$, Cells labeled for the p20 protein (red,arrows) consistently display chromatin condensation (blue, bisbenzimide). P20negative cells have a normal nuclear aspect (arrowheads). $G$, Active caspase-8 (p18) in neurons of layer IV. H, Confocal microscopy confirmed the colocalization of p20 (red) and p18 (green) in layer IV. Arrowheads in $H$ point to tissular alterations characteristic of the core. Scale bars: $A, C$, $240 \mu \mathrm{m} ; B, D, 75 \mu \mathrm{m} ; E, F, 7.5 \mu \mathrm{m} ; G, 20 \mu \mathrm{m} ; H, 24 \mu \mathrm{m}$.

activation in response to ischemia. Analysis of mRNA contents by semiquantitative RT-PCR showed increased levels $1 \mathrm{hr}$ after MCAO (Table 2), suggesting that cleavage of the proform was compensated by active transcription of the gene. 


\begin{tabular}{|c|c|c|c|c|}
\hline & Sham & $30 \mathrm{~min}$ & $1 \mathrm{hr}$ & $3 \mathrm{hr}$ \\
\hline $\begin{array}{c}\text { Pro-caspas } \\
\text { mRNA }\end{array}$ & $100 \pm 10 \%$ & $84^{*} \pm 7 \%$ & $160^{* *} \pm 5 \%$ & $84 \pm 9 \%$ \\
\hline
\end{tabular}

Pro-caspase- 3 mRNA levels are means \pm SEM of three independent experiments with five animals in each group, expressed as percentages of sham values. One-factor ANOVA with Scheffe F test: ${ }^{*} p<0.05,{ }^{* *} p<0.01$ compared to sham.

Table 3. Mitochondrial functional parameters $1 \mathrm{hr}$ after MCAO

\begin{tabular}{lrr} 
& $\begin{array}{l}\text { Sham } \\
(n=9)\end{array}$ & $\begin{array}{l}1 \mathrm{hr} \text { MCAO } \\
(n=8)\end{array}$ \\
\hline $\begin{array}{l}\text { State 3 respiration } \\
(+\mathrm{ADP})\end{array}$ & $69.22 \pm 9.08$ & $50.88 \pm 9.37^{*}$ \\
$\begin{array}{l}\text { State 4 respiration } \\
(-\mathrm{ADP})\end{array}$ & $17.04 \pm 1.09$ & $14.77 \pm 1.68^{*}$ \\
ADP/O & $2.81 \pm 0.67$ & $2.79 \pm 0.77$ \\
\hline
\end{tabular}

Recordings of $\mathrm{O}_{2}$ consumption allowed the calculation of state 3 (ADP-stimulated) respiration, state 4 (resting) respiration, and the $\mathrm{ADP} / \mathrm{O}$ ratio, which indicates the yield of ATP synthesis. State 3 and state 4 respirations are expressed in nanomoles per milligram of protein per minute. Values represent mean \pm SEM of 8-10 measures. Mann-Whitney $U$ test: ${ }^{*} p<0.05$ versus shams.

We next looked for the specific molecular mechanisms involved by analyzing the activation of various factors known to be upstream to caspase-3 in apoptotic pathways.

\section{Early caspase- 3 activation in the core is not related to caspase- 9 or to alterations of mitochondrial respiratory function}

The so-called "mitochondrial pathway" was first investigated by studying the activation of caspase-9. No activation of caspase-9 (Table 1) was observed $1 \mathrm{hr}$ after occlusion. Caspase-9-like activity was significantly increased from $3 \mathrm{hr}$ and was maintained subsequently (Table 1).

Alterations of mitochondrial respiratory activity were analyzed $1 \mathrm{hr}$ after MCAO by studying the coupling of $\mathrm{O}_{2}$ consumption to ATP synthesis in mitochondrial fractions. A slight decrease in both the resting activity and the ADP-stimulated respiration was observed, without, however, modifications of the efficiency of the oxidative phosphorylation (Table 3).

\section{Caspase- 8 is upstream of early caspase- 3 activation in infarct cores}

Activation of caspase-3 may result from activation of death receptor pathways via the activation of caspase- 8 and/or caspase-2. As assessed by cleavage of ac-IETD-AFC, caspase- 8 activity was dramatically increased as soon as $30 \mathrm{~min}$ after occlusion (Table 1). As for caspase-3, a second peak of activation occurred at $12 \mathrm{hr}$. In contrast, cleavage of z-VDVADAFC, which reflects caspase- 2 activation, remained essentially unchanged after ischemia (Table 1).

Data obtained by activity assays for caspase- 8 were confirmed by immunoblots using antibodies specifically directed against the pro-caspase- 8 or its active form, p18 (Fig. $3 A, B$ ). As for caspase-3, protein levels of the precursor were unchanged. Adsorption of the primary antibody with active recombinant enzyme resulted in loss of the staining (Fig. $3 C$ ). In tissue sections processed for immunohistochemistry $1 \mathrm{hr}$ after MCAO, the p18 protein was located in layers IV-V in the core and in scattered neurons in the surrounding penumbral area (Fig. 2C,G). No

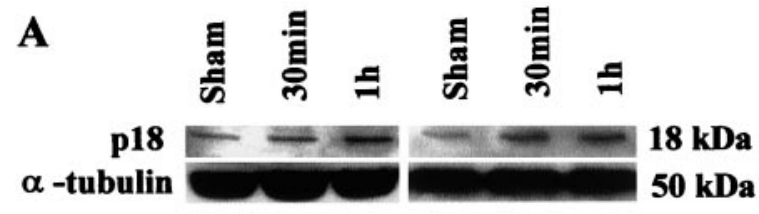

B

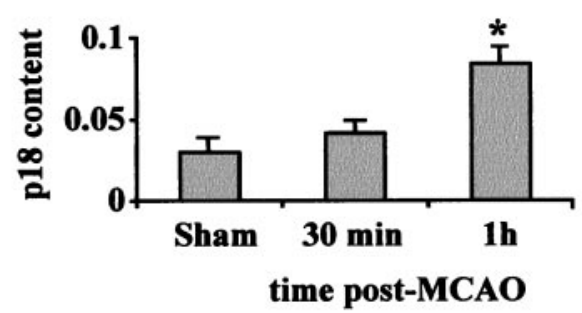

C

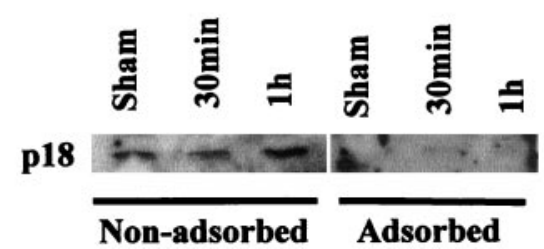

Figure 3. Western blotting $(A)$ and densitometric analysis $(B)$ of active caspase- 8 protein (p18) changes during the early stages of infarction, expressed in arbitrary units against $\alpha$-tubulin. $C$, Immunoblotting with SK440 antibodies adsorbed with an excess of recombinant active caspase-8. Error bars represent mean $\pm \operatorname{SEM}(n=4$ for each time point). ${ }^{*} p<0.05$ versus sham; one-factor ANOVA with Scheffe F test.

labeling was observed in sections incubated with SK440 that was adsorbed with the recombinant protein (Fig. 2D).

Because of its earlier activation, we investigated the potential initiator role of caspase- 8 to caspase-3. First, the colocalization of p20 and p18 within neurons in the core was confirmed by confocal analysis after double labelings with different fluorophores (Fig. $2 H$ ). Second, the caspase- 8 inhibitor z-IETD-fmk was administered intracerebroventricularly (i.c.v.) $30 \mathrm{~min}$ before MCAO. The lack of direct inhibitory effect of z-IETD-fmk on group II caspases, including caspase-3 has already been reported in vitro (Garcia-Calvo et al., 1998). This resulted in the inhibition of not only caspase- 8 but also caspase- 3 , confirming the upstream position of the former in the cascade (Table 4). Inhibition of caspase- 1 activity was also recorded.

\section{Caspase-1 is upstream of caspase- 3 in the activation cascade}

Activation of caspase-3 may result from activation of caspase-1, which was analyzed by cleavage of the sequence YVAD. Caspase-1 displayed a biphasic activation with kinetics identical to those of caspase- 8 (Table 1), pointing to caspase-1 as a second potential trigger of early caspase-3 activation.

Although caspase-1 belongs to group I enzymes, which cleave the sequence YVAD with good specificity (Garcia-Calvo et al., 1998), Western blot analysis of the active form of caspase-1 was performed, which confirmed the increase of active caspase-1 protein at $30 \mathrm{~min}$ and $1 \mathrm{hr}$ after MCAO (Fig. 4). According to previous in vivo data (Yamin et al., 1996), catalysis of prointerleukin 1- $\beta$ converting enzyme (ICE) generated two active forms of 20 and $22 \mathrm{kDa}$, respectively. The two bands showed similar variations.

I.c.v. administration of the caspase-1 inhibitor z-YVAD-cmk 30 


\begin{tabular}{llcccc}
\hline \multicolumn{7}{l}{ Table 4. Effects of caspase-1 and caspase-8 inhibition on caspase-3 activity } \\
\multicolumn{7}{l}{ Inhibitor } & Caspase & Sham & Inhibitor alone & 1 hr MCAO & $\begin{array}{c}\text { Inhibitor + } 1 \\
\text { hr MCAO }\end{array}$ \\
\hline YVAD-CMK & Caspase-1 & $210 \pm 9.5$ & $236 \pm 21.9$ & $326 \pm 9.5^{*}$ & $207 \pm 21.8^{\dagger}$ \\
& Caspase-3 & $52.2 \pm 2.5$ & $36.5 \pm 14.2$ & $209.5 \pm 2.5^{*}$ & $59.7 \pm 20^{\dagger}$ \\
IETD-FMK & Caspase-8 & $221 \pm 12.71$ & $237.61 \pm 15.25$ & $818.36 \pm 1^{* *}$ & $178.92 \pm 10.9^{\dagger}$ \\
& Caspase-8 & $219.7 \pm 12$ & $149.6 \pm 19.3$ & $816.13 \pm 1^{*}$ & $131.2 \pm 9.6^{\dagger}$ \\
& Caspase-3 & $124.8 \pm 18$ & $70.7 \pm 13.3$ & $389 \pm 83^{*}$ & $84 \pm 17.8^{\dagger}$ \\
& Caspase-1 & $46.75 \pm 0.45$ & $52.65 \pm 2.5$ & $163.85 \pm 18.61^{*}$ & $54.64 \pm 5.6^{\dagger}$
\end{tabular}

Values are mean \pm SEM of six determinations. One-factor ANOVA with Scheffe F test: ${ }^{*} p<0.05,{ }^{* *} p<0.01, * * * p<$ $0.001,1$ hr MCAO versus sham; ${ }^{\dagger} p<0.01$, inhibitor +1 hr MCAO versus 1 hr MCAO.

A

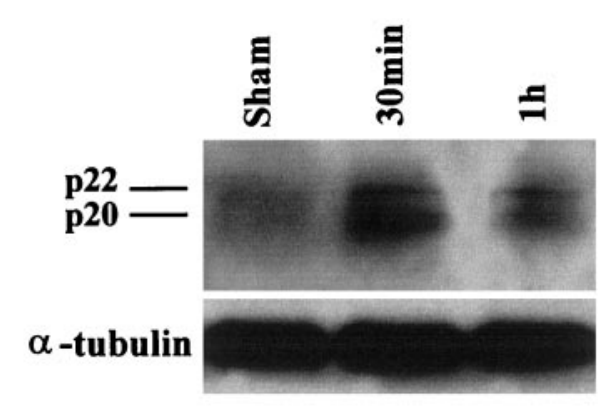

B

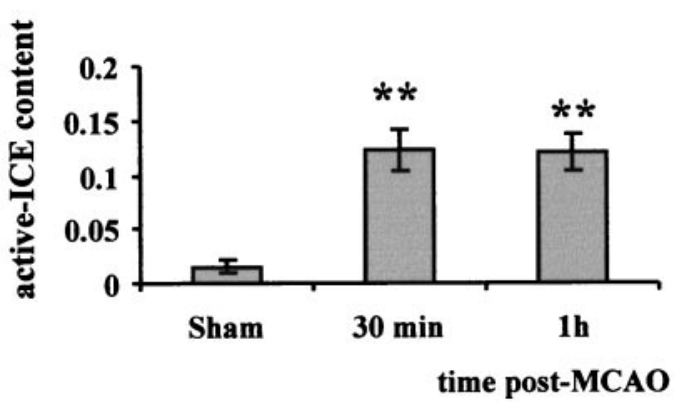

Figure 4. Western blotting $(A)$ and densitometric analysis $(B)$ of active caspase-1 proteins changes during the early stages of infarction, expressed in arbitrary units against $\alpha$-tubulin. The two bands correspond to the two main active fragments of caspase-1. Error bars represent mean \pm SEM ( $n=6$ for sham; $n=5$ for others). $* * p<0.001$ versus sham; one-factor ANOVA with Scheffe F test.

min before ischemia inhibited both caspase- 1 and caspase- 3 activities (Table 4). Considering that z-YVAD-fmk has no direct inhibitory effect on caspase-3 in vitro (Garcia-Calvo et al., 1998), these results show that activation of caspase- 1 is involved in the early activation of caspase- 3 in the core of a focal infarct. Proteolytic activity of caspase- 8 was also inhibited by this treatment, confirming the relationship between both initiator caspases and indicating that this relationship is reciprocal.

\section{DISCUSSION}

The main result of this study is the demonstration of specific caspase activation cascades in the two steps of brain infarction after focal ischemia. In the early stages of infarction, the morphological, biochemical, and physiological criteria of the cortical area that was destined to become "necrotic" suggested instead the existence of progressing apoptosis. Contradictory evidence of morphological and biochemical characteristics of both apoptosis and necrosis in ischemia can be reconciled with our conclusion by assuming that apoptosis is a primary event in cells affected by the loss of blood supply, and that necrosis occurs only secondarily in relationships with rapid depletion of apoptosis-requiring energy stores. In contrast, apoptosis is allowed to proceed in the penumbra, in which sufficient energy levels are kept.

\section{Caspases are activated in infarct cores}

Traditionally, cell death has been considered necrotic in ischemic primary lesions on the basis of location, time elapsed from the insult, loss of basophilia, and presence of karyorrhexis. However, the main characteristics of necrosis, cell and organelle swelling and rupture (Wyllie et al., 1980), are rarely observed in neurons of the core. Rather, the swollen morphology is associated with apoptotic features and cytoplasmic vacuolation (Martin et al., 1998). Furthermore, those observations always refer to late stages of infarction. Our hypothesis was first suggested by the fact that, in the early steps of infarction process, a majority of neurons displayed nuclear and cytoplasmic condensation, which are primary characteristics of apoptosis (Kerr et al., 1972; Searle et al., 1982), and contrast to the swelling observed in necrosis (Trump et al., 1984). The first steps of apoptosis are also reflected in the lack of major mitochondrial functional alterations (Desagher and Martinou, 2000).

The hypothesis was confirmed by the early activation of caspases. Caspase-3 activation is observed in ischemia with varying time course and amplitude, according to the severity of the insult, but these parameters always correlate with the evolution of apoptotic cell death (Chen et al., 1998; Fink et al., 1998; Namura et al., 1998; Velier et al., 1999; Sasaki et al., 2000). In addition, cells in which caspase activities have been blocked display morphological features strikingly close to necrosis (Chautan et al., 1999; Kitanaka and Kuchino, 1999; Samali et al., 1999). We confirm the descriptions of Velier and collaborators (Velier et al., 1999), indicating the presence of activated caspase- 3 in the core of a focal infarct, and show that this activation occurs rapidly after arterial occlusion in neurons that consistently display condensed cytoplasm and nuclei.

A main component of tissue response to ischemia is a rapid increase of extracellular glutamate (Choi, 1995). The subsequent increase of intracellular calcium levels triggers the activation of calpains, another family of proteases that have been mainly implicated in excitotoxicity and necrosis (Wang, 2000). Interestingly, recent reports have demonstrated a relationship between the activation of m-calpain and caspase-3, either directly (Blomgren et al., 2001) or mediated by caspase-12 activation (Nakagawa and Yuan, 2000). These reports confirm the possibility of a link between early calcium-mediated events and the activation of caspase- 3 in cerebral ischemia. 


\section{The two steps of infarction recruit specific apoptotic pathways}

Caspase-3 is a common effector for several independent, yet interacting, activation cascades. These involve pathways related to mitochondria, ligand binding to apoptotic receptors, or internal activation of initiator caspases such as caspase-1 (Nagata, 1997; Ashkenazi and Dixit, 1998).

The so-called mitochondrial pathway is probably the most complex of the caspase activation mechanisms. It originates from the release of a set of pro-apoptotic molecules, among which are the apoptosis-inducing factor (AIF) (Li et al., 1997) and cytochrome C (Kroemer and Reed, 2000). Cytoplasmic leakage of cytochrome $\mathrm{C}$ from the mitochondrial intermembrane space triggers the rapid activation of caspase- 9 in an energy-dependent molecular cluster named the apoptosome (Zou et al., 1997; Rodriguez and Lazebnik, 1999). Active caspase-9 cleaves the executioner caspase-3 (Liu et al., 1996; Li et al., 1997; Cassarino and Bennett, 1999; Slee et al., 1999). Ischemia activates the mitochondrial pathway (Krajewski et al., 1999), and several lines of evidence suggest the involvement of mitochondrial dysfunction in reperfusion damage (Hillered et al., 1985; Almeida et al., 1995; Friberg et al., 1998). We show that, after permanent MCAO, the first wave of activation of caspase- 3 can be dissociated from the activation of caspase-9. Accordingly, cytoplasmic leakage of cytochrome $\mathrm{C}$ is significant in this model only from $3 \mathrm{hr}$ after MCAO (Guégan and Sola, 2000). In agreement with the upstream position of caspase-9, the activation of caspase- 9 in the second phase starts earlier than that of caspase-3. The activation of the mitochondrial pathway is therefore a delayed event, linked to secondary damage in the penumbra but unrelated to the initial lesion. Activation of the apoptosome in the penumbra is consistent with the ATP-dependency of the process (Hu et al., 1999), because ATP levels rapidly fall in the core when residual energy remains in the peri-infarct area (Back et al., 2000).

Our results also show that the efficiency of the oxidative phosphorylation is maintained during the first step of infarction. Alterations of mitochondrial membranes induce a leakage of protons back across the membranes and increase the resting respiration, thus compromising ATP synthesis (Murphy et al., 1999). The lack of acceleration of the resting respiration therefore indicates that inner mitochondrial membranes were still intact $1 \mathrm{hr}$ after MCAO.

The "death receptors" pathways involve caspase-8, caspase-2, and caspase-10 (Boldin et al., 1996; Duan and Dixit, 1997; Nagata, 1997). Apoptotic receptors are members of the tumor necrosis factor receptor superfamily, which triggers the caspase cascade through cytosolic adaptor proteins (Chinnaiyan et al., 1995; Hsu et al., 1995). Activated caspase- 8 drives its activation through self-cleavage (Muzio et al., 1998) and activates caspase-3 (Ashkenazi and Dixit, 1998; Van de Craen et al., 1999). Activation of effector caspases by receptor binding in ischemia is observed mainly after reperfusion, in correlation with their role in inflammatory processes and formation of vasogenic edema (Schielke et al., 1998). We show that, in addition to its involvement in delayed cell death in the penumbra, caspase- 8 can trigger activation of caspase- 3 in the core.

Scaffidi and colleagues have suggested the existence of two different CD95-signaling pathways (Scaffidi et al., 1998). In the type- 1 pathway, caspase- 8 and caspase- 3 are activated sequentially and independently of mitochondrial activity. In type- 2 cell death, activation of both caspases is concomitant, delayed, and

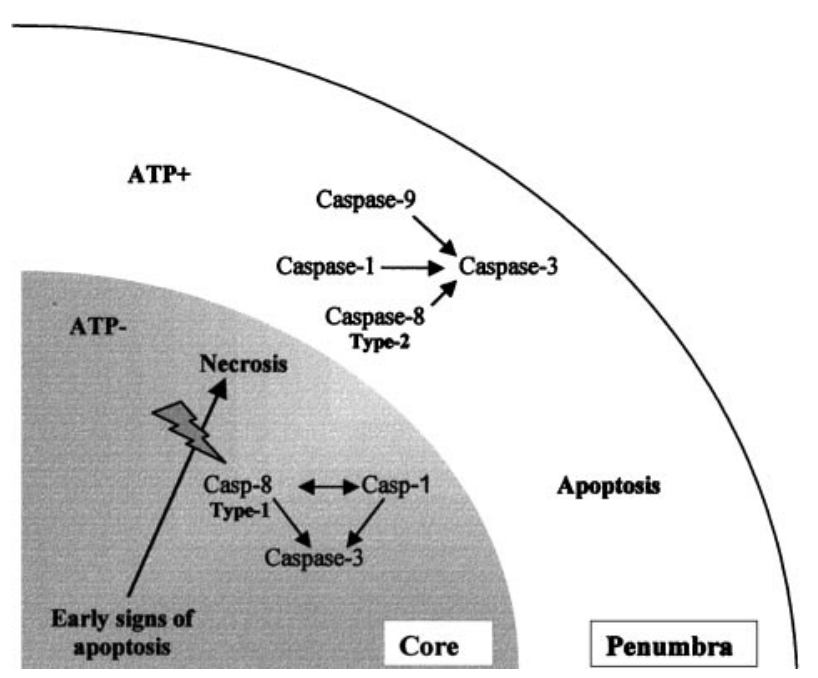

Figure 5. Caspases participate in both steps of brain infarction by means of discrete pathways. Initial lesion (Core) and its expansion (Penumbra). Each step is characterized by the involvement of specific caspase activation cascades. Initial commitment to apoptosis may shift to necrosis with rapid worsening of energetic conditions in the core, whereas evolution of the full process is allowed in the peri-infarct area.

dependent on mitochondrial function. According to this classification, initial cell death in infarct cores would be of the mitochondrial-independent type-1, whereas secondary cell death, leading to infarct expansion, would be of the mitochondrialdependent, type-2 pathway (Fig. 4). Our investigations also confirmed that caspase- 2 is not involved in ischemic brain damage (Schotte et al., 1998).

ICE was the first identified mammalian homolog of the Caenorhabditis elegans cell-death gene product of the CED family (Yuan et al., 1993). Subsequently named caspase-1, ICE is one of the caspases with caspase-activating recruitment domains (CARDs) that activates caspase-3 (Enari et al., 1996; Van de Craen et al., 1999). As for caspase-8, caspase- 1 is activated by reperfusion after global ischemia (Bhat et al., 1996; Honkaniemi et al., 1996). Reduced infarct volumes are observed in caspase-1-deficient mice (Schielke et al., 1998) and in mice expressing a dominant negative inhibitor of caspase-1 (Friedlander et al., 1997; Hara et al., 1997). We show that ICE shares with caspase- 8 an upstream position in activating caspase- 3 in focal infarct cores and that caspase- 1 and caspase- 8 can be reciprocally activated, which suggests the existence of an amplification loop involving the three caspases.

Apoptotic mechanisms identified in the present study are summarized on Figure 5. They point to an interesting specificity of the cascades involved in cell death in the core of the infarct, as compared with those identified during the secondary expansion of the lesion in the penumbral area. In contrast to the latter, which depends on apoptotic pathways involving the release of proapoptotic factors from the intermembrane zone of mitochondria, and subsequent activation of caspase-9, apoptotic cascades in the core of the infarct rely on different mechanisms and involve caspases activated by ligand binding to specific death receptors and by the prototypic caspase- 1 . This emphasizes the complexity of regulatory functions of the caspases in neuronal death induced by acute brain lesions.

\section{Conclusion}

It has been suggested that the ultimate choice between apoptosis and necrosis depends on energy levels in the affected cells (Nico- 
tera et al., 1998). In cerebral ischemia, energy levels are severely impaired, with near to zero levels in the infarct core and a centrifuge gradient from the core toward the periphery of the damaged territory. Energy levels are maintained in the penumbra because of retrograde perfusion from adjacent arteries via anastomosis, giving an opportunity for neuronal apoptosis to fully develop. Along that line, the present results suggest that secondary necrosis results from a rapid failure to fully develop the apoptotic program because of the maintained depletion of apoptosis-requiring energy stores in the core. Such a dual mechanism may have clinical relevance because it is assumed that, given the lack of potential "anti-necrotic" factors, cell death observed in the core of the infarct is beyond reach of therapeutics (Jonas et al., 1999). In contrast, factors interfering with apoptotic cascades are actively developed for clinical purposes (Johnson, 2000; Nicholson, 2000). The demonstration that apoptotic cascades are triggered primarily in neurons of the infarct core may allow antiapoptotic agents to affect the volume of this area by prolonging the window before reperfusion of the territory.

\section{REFERENCES}

Almeida A, Allen KL, Bates TE, Clark JB (1995) Effect of reperfusion following cerebral ischaemia on the activity of the mitochondrial respiratory chain in the gerbil brain. J Neurochem 65:1698-1703.

Ashkenazi A, Dixit VM (1998) Death receptors: signaling and modulation. Science 281:1305-1308.

Back T, Hoehn M, Mies G, Busch E, Schmitz B, Kohno K, Hossmann KA (2000) Penumbral tissue alkalosis in focal cerebral ischemia: relationship to energy metabolism, blood flow, and steady potential. Ann Neurol 47:485-492.

Bhat RV, DiRocco R, Marcy VR, Flood DG, Zhu Y, Dobrzanski P, Siman R, Scott R, Contreras PC, Miller M (1996) Increased expression of IL-1beta converting enzyme in hippocampus after ischemia: selective localization in microglia. J Neurosci 16:4146-4154.

Blomgren K, Zhu C, Wang X, Karlsson JO, Leverin AL, Bahr BA, Mallard C, Hagberg H (2001) Synergistic activation of caspase-3 by $\mathrm{m}$-calpain after neonatal hypoxia-ischemia: a mechanism of "pathological apoptosis.” J Biol Chem 276:10191-10198.

Boldin MP, Goncharov TM, Goltsev YV, Wallach D (1996) Involvement of MACH, a novel MORT1/FADD-interacting protease, in Fas/ APO-1- and TNF receptor-induced cell death. Cell 85:803-815.

Cassarino DS, Bennett Jr JP (1999) An evaluation of the role of mitochondria in neurodegenerative diseases: mitochondrial mutations and oxidative pathology, protective nuclear responses, and cell death in neurodegeneration. Brain Res Rev 29:1-25.

Charriaut-Marlangue C, Aggoun-Zouaoui D, Represa A, Ben-Ari Y (1996) Apoptotic features of selective neuronal death in ischemia, epilepsy and gp 120 toxicity. Trends Neurosci 19:109-114.

Chautan M, Chazal G, Cecconi F, Gruss P, Golstein P (1999) Interdigital cell death can occur through a necrotic and caspase-independent pathway. Curr Biol 9:967-970.

Chen J, Nagayama T, Jin K, Stetler RA, Zhu RL, Graham SH, Simon RP (1998) Induction of caspase-3-like protease may mediate delayed neuronal death in the hippocampus after transient cerebral ischemia. J Neurosci 18:4914-4928.

Chinnaiyan AM, O'Rourke K, Tewari M, Dixit VM (1995) FADD, a novel death domain-containing protein, interacts with the death domain of Fas and initiates apoptosis. Cell 81:505-512.

Choi DW (1995) Calcium: still center-stage in hypoxic-ischemic neuronal death. Trends Neurosci 18:58-60.

Choi DW (1996) Ischemia-induced neuronal apoptosis. Curr Opin Neurobiol 6:667-672.

Cohen GM (1997) Caspases: the executioners of apoptosis. Biochem J 326:1-16.

Desagher S, Martinou JC (2000) Mitochondria as the central control point of apoptosis. Trends Cell Biol 10:369-377.

Duan H, Dixit VM (1997) RAIDD is a new "death" adaptor molecule. Nature 385:86-89.

Enari M, Talanian RV, Wong WW, Nagata S (1996) Sequential activation of ICE-like and CPP32-like proteases during Fas-mediated apoptosis. Nature 380:723-726.

Endres M, Namura S, Shimizu-Sasamata M, Waeber C, Zhang L, GomezIsla T, Hyman BT, Moskowitz MA (1998) Attenuation of delayed neuronal death after mild focal ischemia in mice by inhibition of the caspase family. J Cereb Blood Flow Metab 18:238-247.

Fink K, Linmin Z, Namura S, Shimizu-Sasamata M, Endres M, Ma J, Dalkara T, Yuan J, Moskowitz M (1998) Prolonged therapeutic win- dow for ischemic brain damage caused by delayed caspase activation. J Cereb Blood Flow Metab 18:1071-1076.

Friberg H, Ferrand-Drake M, Bengtsson F, Halestrap AP, Wieloch T (1998) Cyclosporin A, but not FK 506, protects mitochondria and neurons against hypoglycemic damage and implicates the mitochondrial permeability transition in cell death. J Neurosci 18:5151-5159.

Friedlander RM, Gagliardini V, Hara H, Fink KB, Li W, MacDonald G, Fishman MC, Greenberg AH, Moskowitz MA, Yuan J (1997) Expression of a dominant negative mutant of interleukin-1 beta converting enzyme in transgenic mice prevents neuronal cell death induced by trophic factor withdrawal and ischemic brain injury. J Exp Med 185:933-940.

Fujikawa DG (2000) Confusion between neuronal apoptosis and activation of programmed cell death mechanisms in acute necrotic insults. Trends Neurosci 23:410-411.

Garcia JH, Liu KF, Ho KL (1995) Neuronal necrosis after middle cerebral artery occlusion in Wistar rats progresses at different time intervals in the caudoputamen and the cortex. Stroke 26:636-642.

Garcia-Calvo M, Peterson EP, Leiting B, Ruel R, Nicholson DW, Thornberry NA (1998) Inhibition of human caspases by peptide-based and macromolecular inhibitors. J Biol Chem 273:32608-32613.

Guégan C, Sola B (2000) Early and sequential recruitment of apoptotic effectors after focal permanent ischemia in mice. Brain Res 856:93-100.

Guégan C, Onténiente B, Makiura Y, Merad-Boudia M, Ceballos-Picot I, Sola B (1998) Reduction of cortical infarction and impairment of apoptosis in NGF-transgenic mice subjected to permanent focal ischemia. Mol Brain Res 55:133-140.

Gwag BJ, Lobner D, Koh JY, Wie MB, Choi DW (1995) Blockade of glutamate receptors unmasks neuronal apoptosis after oxygen-glucose deprivation in vitro. Neuroscience 68:615-619.

Hara H, Fink K, Endres M, Friedlander RM, Gagliardini V, Yuan J, Moskowitz MA (1997) Attenuation of transient focal cerebral ischemic injury in transgenic mice expressing a mutant ICE inhibitory protein. J Cereb Blood Flow Metab 17:370-375.

Harrison DC, Medhurst AD, Bond BC, Campbell CA, Davis RP, Philpott KL (2000) The use of quantitative RT-PCR to measure mRNA expression in a rat model of focal ischemia-caspase-3 as a case study. Brain Res Mol Brain Res 75:143-149.

Hengartner MO (2000) The biochemistry of apoptosis. Nature 407:770-776.

Hillered L, Smith ML, Siesjo BK (1985) Lactic acidosis and recovery of mitochondrial function following forebrain ischemia in the rat. J Cereb Blood Flow Metab 5:259-266.

Himi T, Ishizaki Y, Murota S (1998) A caspase inhibitor blocks ischemia-induced delayed neuronal death in the gerbil. Eur J Neurosci 10:777-781.

Honkaniemi J, Massa SM, Breckinridge M, Sharp FR (1996) Global ischemia induces apoptosis-associated genes in hippocampus. Mol Brain Res 42:79-88.

Hsu H, Xiong J, Goeddel DV (1995) The TNF receptor 1-associated protein TRADD signals cell death and NF-kappa B activation. Cell 81:495-504.

Hu Y, Benedict MA, Ding L, Nunez G (1999) Role of cytochrome c and dATP/ATP hydrolysis in Apaf-1-mediated caspase-9 activation and apoptosis. EMBO J 18:3586-3595.

Johnson DE (2000) Programmed cell death regulation: basic mechanisms and therapeutic opportunities. Leukemia 14:1340-1344.

Jonas S, Ayigari V, Viera D, Waterman P (1999) Neuroprotection against cerebral ischemia. A review of animal studies and correlation with human trial results. Ann NY Acad Sci 890:2-3.

Kerr JF, Wyllie AH, Currie AR (1972) Apoptosis: a basic biological phenomenon with wide-ranging implications in tissue kinetics. $\mathrm{Br} J$ Cancer 26:239-257.

Kitanaka C, Kuchino Y (1999) Caspase-independent programmed cell death with necrotic morphology. Cell Death Differ 6:508-515.

Krajewski S, Krajewska M, Ellerby LM, Welsh K, Xie Z, Deveraux QL, Salvesen GS, Bredesen DE, Rosenthal RE, Fiskum G, Reed JC (1999) Release of caspase-9 from mitochondria during neuronal apoptosis and cerebral ischemia. Proc Natl Acad Sci USA 96:5752-5757.

Kroemer G, Reed JC (2000) Mitochondrial control of cell death. Nat Med 6:513-519.

Leist M, Single B, Castoldi AF, Kuhnle S, Nicotera P (1997) Intracellular adenosine triphosphate (ATP) concentration: a switch in the decision between apoptosis and necrosis. J Exp Med 185:1481-1486.

Li H, Yuan J (1999) Deciphering the pathways of life and death. Curr Opin Cell Biol 11:261-266.

Li P, Nijhawan D, Budihardjo I, Srinivasula SM, Ahmad M, Alnemri ES, Wang X (1997) Cytochrome c and dATP-dependent formation of Apaf-1/caspase-9 complex initiates an apoptotic protease cascade. Cell 91:479-489.

Li Y, Chopp M, Jiang N, Yao F, Zaloga C (1995) Temporal profile of in situ DNA fragmentation after transient middle cerebral artery occlusion in the rat. J Cereb Blood Flow Metab 15:389-397.

Linnik MD, Zobrist RH, Hatfield MD (1993) Evidence supporting a 
role for programmed cell death in focal cerebral ischemia in rats. Stroke 24:2002-2008.

Lipton P (1999) Ischemic cell death in brain neurons. Physiol Rev 79:1431-568.

Liu X, Kim CN, Yang J, Jemmerson R, Wang X (1996) Induction of apoptotic program in cell-free extracts: requirement for dATP and cytochrome c. Cell 86:147-157.

Mao Y, Yang GY, Zhou LF, Stern JD, Betz AL (1999) Focal cerebral ischemia in the mouse: description of a model and effects of permanent and temporary occlusion. Mol Brain Res 63:366-370.

Martin LJ, Al-Abdulla NA, Brambrink AM, Kirsch JR, Sieber FE, Portera-Cailliau C (1998) Neurodegeneration in excitotoxicity, global cerebral ischemia, and target deprivation: a perspective on the contributions of apoptosis and necrosis. Brain Res Bull 46:281-309.

Melino G, Catani MV, Corazzari M, Guerrieri P, Bernassola F (2000) Nitric oxide can inhibit apoptosis or switch it into necrosis. Cell Mol Life Sci 57:612-622.

Murphy AN, Fiskum G, Beal MF (1999) Mitochondria in neurodegeneration: bioenergetic function in cell life and death. J Cereb Blood Flow Metab 19:231-245.

Muzio M, Stockwell BR, Stennicke HR, Salvesen GS, Dixit VM (1998) An induced proximity model for caspase- 8 activation. J Biol Chem 273:2926-2930.

Nagata S (1997) Apoptosis by death factor. Cell 88:355-365.

Nakagawa T, Yuan J (2000) Cross-talk between two cysteine protease families. Activation of caspase-12 by calpain in apoptosis. J Cell Biol $150: 887-894$

Nakane PK (1968) Simultaneous localization of multiple tissue antigens using the peroxidase-labeled antibody method: a study on pituitary glands of the rat. J Histochem Cytochem 16:557-560.

Namura S, Zhu J, Fink K, Endres M, Srinivasan A, Tomaselli KJ, Yuan J, Moskowitz MA (1998) Activation and cleavage of caspase-3 in apoptosis induced by experimental cerebral ischemia. J Neurosci 18:3659-3668.

Nicholson DW (2000) From bench to clinic with apoptosis-based therapeutic agents. Nature 407:810-816.

Nicholson DW, Thornberry NA (1997) Caspases: killer proteases. Trends Biochem Sci 22:299-306.

Nicotera P, Leist M, Ferrando-May E (1998) Intracellular ATP, a switch in the decision between apoptosis and necrosis. Toxicol Lett 102-103:139-142.

Plesnila N, Moskowitz MA (2000) Caspases in cerebral ischemia. In: Pharmacology of cerebral ischemia (Krieglstein J and Klumpp S, eds), pp 137-143. Stuttgart, Germany: Medpharm Scientific.

Rodriguez J, Lazebnik Y (1999) Caspase-9 and APAF-1 form an active holoenzyme. Genes Dev 13:3179-3184.

Roy M, Sapolsky R (1999) Neuronal apoptosis in acute necrotic insults: why is this subject such a mess? Trends Neurosci 22:419-422.

Samali A, Nordgren H, Zhivotovsky B, Peterson E, Orrenius S (1999) A comparative study of apoptosis and necrosis in HepG2 cells: oxidantinduced caspase inactivation leads to necrosis. Biochem Biophys Res Commun 255:6-11.
Sasaki C, Kitagawa H, Zhang WR, Warita H, Sakai K, Abe K (2000) Temporal profile of cytochrome $\mathrm{c}$ and caspase-3 immunoreactivities and TUNEL staining after permanent middle cerebral artery occlusion in rats. Neurol Res 22:223-228.

Scaffidi C, Fulda S, Srinivasan A, Friesen C, Li F, Tomaselli KJ, Debatin KM, Krammer PH, Peter ME (1998) Two CD95 (APO-1/Fas) signaling pathways. EMBO J 17:1675-1687.

Schielke GP, Yang GY, Shivers BD, Betz AL (1998) Reduced ischemic brain injury in interleukin-1 beta converting enzyme-deficient mice. J Cereb Blood Flow Metab 18:180-185.

Schotte P, Van Criekinge W, Van de Craen M, Van Loo G, Desmedt M, Grooten J, Cornelissen M, De Ridder L, Vandekerckhove J, Fiers W, Vandenabeele P, Beyaert R (1998) Cathepsin B-mediated activation of the proinflammatory caspase-11. Biochem Biophys Res Commun 251:379-387.

Searle J, Kerr JF, Bishop CJ (1982) Necrosis and apoptosis: distinct modes of cell death with fundamentally different significance. Pathol Annu 17:229-259.

Shigeno T, McCulloch J, Graham DI, Mendelow AD, Teasdale GM (1985) Pure cortical ischemia versus striatal ischemia. Circulatory, metabolic, and neuropathologic consequences. Surg Neurol 24:47-51.

Slee EA, Harte MT, Kluck RM, Wolf BB, Casiano CA, Newmeyer DD, Wang HG, Reed JC, Nicholson DW, Alnemri ES, Green DR, Martin SJ (1999) Ordering the cytochrome c-initiated caspase cascade: hierarchical activation of caspases-2, -3, -6, -7, -8, and -10 in a caspase-9dependent manner. J Cell Biol 144:281-292.

Trump BF, Berezesky IK, Sato T, Laiho KU, Phelps PC, DeClaris N (1984) Cell calcium, cell injury and cell death. Environ Health Perspect 57:281-287.

Van de Craen, M, Declercq W, Van den brande I, Fiers W, and Vandenabeele P (1999) The proteolytic procaspase activation network: an in vitro analysis. Cell Death Differ 6:1117-1124.

Velier JJ, Ellison JA, Kikly KK, Spera PA, Barone FC, Feuerstein GZ (1999) Caspase-8 and caspase-3 are expressed by different populations of cortical neurons undergoing delayed cell death after focal stroke in the rat. J Neurosci 19:5932-5941.

Wang KK (2000) Calpain and caspase: can you tell the difference? Trends Neurosci 23:20-26.

Wyllie AH, Kerr JF, Currie AR (1980) Cell death: the significance of apoptosis. Int Rev Cytol 68:251-306.

Yamin TT, Ayala JM, Miller DK (1996) Activation of the native 45-kDa precursor form of interleukin-1-converting enzyme. J Biol Chem 271:13273-13282

Yuan J, Shaham S, Ledoux S, Ellis HM, Horvitz HR (1993) The $C$. elegans cell death gene ced-3 encodes a protein similar to mammalian interleukin-1 beta-converting enzyme. Cell 75:641-652.

Zini R, Simon N, Morin C, d'A this P, Tillement JP (1996) Inhibition of rat cerebral mitochondrial respiration by cyclosporins $\mathrm{A}, \mathrm{D}$, and $\mathrm{G}$ and restoration with trimetazidine. C R Acad Sci III 319:1087-1092.

Zou H, Henzel WJ, Liu X, Lutschg A, Wang X (1997) Apaf-1, a human protein homologous to C. elegans CED-4, participates in cytochrome c-dependent activation of caspase-3. Cell 90:405-413. 